Fibroblast migration, proliferation, extacellular matrix protein synthesis and degradation are the key events in various biological and pathological processes in pulmonary fibrosis. In addition, biopsy specimens from the lungs of patients with plumomary fibrosis show increased numbers of mast cells which have metachromatic granules containing heparin, histamin and proteases. Little is known about how these products influence pulmonary fibrosis. In the present study, we investigated the effect of heparin and related glycosaminoglycans on PDGFinduced lung fibroblast proliferation and chemotactic response in vitro. In addition, we examined the effect of heparin on both the induction of matorix metalloproteinases (MMPs) and MMPs activity in lung fibroblasts in vitro.

Heparin, de-N-sulphated heparin but not heparan sulphate inhibited PDGF-induced lung fibroblast proliferation. In contrast, only heparin in hibited PDGFstimulated human lung fibroblast chemotax is. Negatively charged poly- $L$-gultamic acid had no effect on either fibroblast proliferation or chemotaxis. Thus the negative charge alone cannot account for the ant-proliferative and anti-chemotactic effects of heparin.

Furthermore, heparin and heparan sulphate also had no inhibitory effect on induction of MMPs, including MMP-1 (interstitial collagenase), MMP-2 (gelatin as e A) and MMP-9 (gelatin ase B). Only heparin inhibited both MMP-1 and MMP-2/MMP-9 activity. Additionally, tissue inhibitor of metalloproteinase type 1 (TIMP-1) and type 2 (TIMP-2) inhibited PDGFstimulated human lung fibroblast chemotaxis. The ability of heparin to inhibit fibroblast chemotaxis may account for the inhibitory effect of heparin on MMP activity.

The above results suggested that heparin and related glycosaminoglycans differentially regulate PDGF-induced lung fibroblast proliferation, chemotax is and MMPs activity and further that these effects may have a key role in extracellular matrix remodeling in inflam matory lung disease.

Key words: Heparin, PDGF, Matorix metalloproteinases (MMPs), Lung fibroblasts, Pulmonary fibrosis

\section{Effect of heparin and related glycosaminoglycan on PDGF-induced lung fibroblast proliferation, chemotactic response and matrix metalloproteinases activity}

\author{
Masahiro Sasaki ${ }^{\mathrm{CA}}$, Masayuki Kashima, \\ Takefumi Ito, Akiko Watanabe, Masaaki Sano, \\ Manabu Kagaya, Takanobu Shioya and \\ Mamoru Miura
}

Second Department of Internal Medicine, Akita University School of Medicine, 1-1-1 Hondo, Akita 010, Japan

${ }^{C A}$ Corresponding Author
Tel: +81188846107
Fax: +81 188362612
E-mail: masahiro@im2.med.akita-u.ac.jp

\section{Introduction}

Biopsy specimens from the lungs of patients with plumonary fibrosis show increased numbers of mast cells ${ }^{1-3}$ which have metachromatic granules containing heparin, histamine and proteases. Morphological studies also suggested fibroblast proliferation, excessive synthesis and deposition of collagen and other extracellular matrix proteins $s^{4,5}$ in pulmonary fibrosis. However, less is known about the interaction of fibroblasts, growth factors and extracellular matrix molecules in inflammation.
Platelet-derived grow th factor (PDGF), which is one of the most important mitogens derived from various cells including alveolar macrophages and platelets, may implicate the extracellular matrix proteins and matrix metalloproteinases (MMPs) ${ }^{6}$ in wound healing. The role of PDGF in inflammatory lung diseases is consistent with the observation of PDGF-like proteins localised to macrophages and epithelial cells associated with tissue repair of patients with idiopathic pulmonary fibrosis. ${ }^{7,8}$

Mast-cell mediators may act as grow th factors, including histamine and tryptase, to fibroblasts. Hep- 
arin, a major component of the mast cell granule matrix and well know $\mathrm{n}$ polyanionic anticoagulant, is now recognised as an anti-inflammatory agent. Heparin and heparin related glycosaminoglycans have numerous other functions, among which are inhibition of fibrin deposition in tissues, ${ }^{9}$ inhibition of fibroblast proliferation associated with protease ${ }^{10,11}$ and inhibition of allergen-induced recruitment of eosinophils into the airw ay. ${ }^{12-14} \mathrm{Heparin}$ and heparan sulphate, which is one of the main extracellular matrix components, also inhibit vascular smooth muscle cell division. ${ }^{15,16}$ This action may indicate that heparin and related glycosaminoglycans play an important role in modulation not only of airway wall remodelling in asthma ${ }^{17,18}$ but also of extracellular matrix remodeling in pulmonary fibrosis.

MMPs are major proteolytic enzymes involved in degrading and remodeling the extracellular matrix. The matrix metalloproteinase-1 (MMP-1) derived from fibroblasts is interstitial collagenase know $\mathrm{n}$ to degrade collagen types I, II, III and others. ${ }^{19}$ The type IV collagenase (MMP-2 and MMP-9), which is now found in fibroblasts and macrophages has the ability to degrade a wide range of extracellular matrix proteins, including basement membrane collagen type IV, fibronectin and gelatin. ${ }^{20,21}$ Recently, it has been suggested that MMPs including MMP-2, MMP-3 and MMP-9 play a major role in the degradation of the ex tracellular matrix during tumor cell invasion. ${ }^{17,18}$ In pulmonary fibrosis, MMPs are regulated by numerous factors including growth factors and inflammatory mediators may play a key role in modulating lung tissue injury and extracellular matrix remodeling.

Therefore, in the present study we investigate the possible influence of heparin and glycosaminoglycan on PDGF-induced human lung fibroblast prolife ration, chemotax is and MMPs activity.

\section{Material and methods}

\section{Materials}

Recombinant human PDGF-BB was purchased from Genzyme (USA). Heparin (porcine), whose activity was 1000 units perml, was purchased from Novo Nordlisk (Denmark). Heparan sulphate (bovine mucosa), de-N-sulphated heparin and poly-L-gultamic acid were obtained from Sigma (USA). Anti-hMMP1, anti-hMMP2 and anti-hMMP9 were purchased from Fuji Chemi Co. (Japan), as were recombinant h TIMP-1 and hTIMP-2. Tissue culture plates were obtained from Sumitomo Bakelite (Japan) and transwell culture dishes were from Corning Coster (USA).

\section{Cell culture, proliferation and adhesion}

Human lung fibroblasts CCL-153 obtained from the American Type Culture Collection (ATCC) were cul- tured in a cell culture flask, in modified Ham's F12 (Sigma) supplemented with $10 \% \mathrm{FCS}$ at $37^{\circ} \mathrm{C}$ in an atomosphere of $5 \% \mathrm{CO}_{2}$. The cells were plated at 1.0 $\times 10^{5}$ cells in a 24 -well plate in media with $10 \%$ FCS for $72 \mathrm{~h}$ then washed three times in F12, and synchronized with serum free F12 for $48 \mathrm{~h}$. Cells were incubated with heparin $(0.1-100 \mathrm{U} / \mathrm{ml})$, heparan sulphate, de-N-sulphated heparin and poly-L-gultamic acid $(0.1-100 \mathrm{~g} / \mathrm{ml})$ with serum free media for $24 \mathrm{~h}$. Cells were removed from plates with PBS and EDTA, replaced and suspended in a microtest tube with $1 \mathrm{ml}$ of F12 media. Cell counts and viability were determined by trypan blue exclusion (GIBCO) and counted in a hemocytometer.

\section{$\left[\mathrm{H}^{3}\right]$-Thymidine incorporation assay}

Lung fibroblasts were plated at $1.0 \times 10^{5}$ cells in a 24-w ell plate in media with $10 \%$ FCS until confluence. Cells were washed three times in F12, and incubated in serum-free F12 medium with compounds pulsed with $\left[\mathrm{H}^{3}\right]$-thymidine $(0.04 \mu \mathrm{Ci} / \mathrm{ml})$. Incorporation of $\left[\mathrm{H}^{3}\right]$-thymidine was measured after $24 \mathrm{~h}$ by detaching the cells with trypsin solution, harvesting the cells on filters using the Tiltertek cell harvester and undergoing lysis with distilled water. Radioactivity on the filters was determined by scintillation counting of $\mathrm{dpm} / \mathrm{w}$ ell.

\section{Chemotaxis assay}

Chemotaxis stimulated by PDGF $(10 \mu \mathrm{g} / \mathrm{ml})$ was measured using the modified Boyden chamber as described previously. ${ }^{22}$ The test compounds diluted with Ham's F12 medium were placed lower in wells in the lower chamber. The wells were covered with a collagen (type I and type III)-coated polycarbonate filter. Human lung fibloblasts $5 \times 10^{4}$ cells and medium were added to the wells in the upper chamber. Anti-hMMP1, anti-hMMP2, anti-hMMP9, recombinant hTIMP-1 and hTIMP-2 were added to the wells in the upper chamber for the chemotactic inhibition assay. After $8 \mathrm{~h}$ incubation at $37^{\circ} \mathrm{C}$ in $5 \% \mathrm{CO}_{2}$, the filters were removed and cells were fixed and stained using Diff-Quik stain. The chemotactic response was determined by counting the number of cells/microscopic field on the lower surface.

\section{Matrix metalloproteinases assay}

An assay to determine matrix metalloproteinases (MMPs) activity was measured by the diffuse fibril method based on that of Cawston and Barrett. This method utilizes FITC labeled type I collagen (human) (MMP-1 activity) or type IV collagen (bovine) (MMP2/MMP-9 activity) which was affected by collagenases incubated at $37^{\circ} \mathrm{C}$ or at $42^{\circ} \mathrm{C}$ to produce soluble fragments that can be separated from intact fibrils by 
centrifugation. One unit of MMP-1 or MMP-2/MMP-9 activity is defined as the amount of enzyme degrading $1 \mu \mathrm{g}$ of collagen per minute at 37 or $42^{\circ} \mathrm{C}$. The specificity of the assay was confirmed by identification of MMPs reaction products using an immunofluoresence electrophotometer as described previously. ${ }^{23}$

\section{Reverse transcription polymerase chain reaction amplification (RT-PCR)}

Total RNA was ex tracted from fibroblasts by RNAzol(). First-strand cDNA was prepared from $3 \mu \mathrm{g}$ total RNA in $30 \mu \mathrm{l}$ reaction volume, $50 \mathrm{mMTris}(\mathrm{pH} 8.3), 75 \mathrm{mM}$ $\mathrm{KCl}, 3 \mathrm{mM} \mathrm{MgCl} 2,10 \mathrm{mM}$ DTT, $1 \mathrm{mM}$ dNTPs, $40 \mathrm{U}$ RNAse inhibitor and $200 \mathrm{U}$ reverse transcriptase.

Oligonucleotide primers for PCR amplification of MMP-1, MMP-2 and MMP-9 were designed according to published sequences for MMP-1, MMP-2 and MMP9. Primers used were as follows: MMP-1: 5'AAGGTTAGCTTACTGTCACACGCTT,3'AGAACGAGAACACAAAGATCTCAGC; MMP-2: 5'CTTTGCAGGAGACAAGTTCTGG,3'TTAAGGTGGTGCAGGTATCTGC; and MMP-9: $\quad$ 5'CCATGAGTCCCTGGCAG,3'TCCCCCTGCCCTCAGAGAA.

Amplification was performed in a final volume of $25 \mu 1$ with $10 \mathrm{mMTris}$ (pH8.3), $50 \mathrm{mM} \mathrm{KCl}, 1.5 \mathrm{mM}$ $\mathrm{MgCl}_{2}, 1.25 \mathrm{mMdNTPs}, 7.5 \mathrm{pmol}$ of each primer and 1.25 of Taq polymerase. After a 'hotstart' $\left(95^{\circ} \mathrm{C}\right.$, $5 \mathrm{~min}$ ), each $3 \mathrm{~min}$ cycle consisted of $1 \mathrm{~min}$ of denaturation at $95^{\circ} \mathrm{C}$, annealing at $55^{\circ} \mathrm{C}$, and elongation at $72^{\circ} \mathrm{C}$. Reactions were run for 30 cycles.

\section{Data analysis}

Results are expressed as mean and s.e.mean. A comparison of proliferation and chemotaxis on dose response within expriments was performed by ANOVA. Statistical significance was established at the $p<0.05$ level. The effects of stimulation/inhibition on fibroblast migration were evaluated using an analysis of variance and were considered statistically significant at the $p<0.05$ level.

\section{Results}

\section{The effect of glycosaminoglycans on PDGF-induced fibroblast proliferation}

PDGF induced a concentration related cell proliferation between 0.1 and $100 \mathrm{ng} / \mathrm{ml}$ (Fig. 1). Heparin alone $(0.1$ and $10 \mathrm{U} / \mathrm{ml})$ had no significant effect on fibroblast proliferation. How ever, at higher concentration heparin $(100 \mathrm{U} / \mathrm{ml})$ did cause a significant inhibition of fibroblast proliferation compared with the control (Fig. 1, $p<0.05$ ).

Heparan sulphate, de-N-suphated heparin and poly$L$-gultamic acid $(0.1-100 \mu \mathrm{g} / \mathrm{ml})$ had no significant effect on cell proliferation.

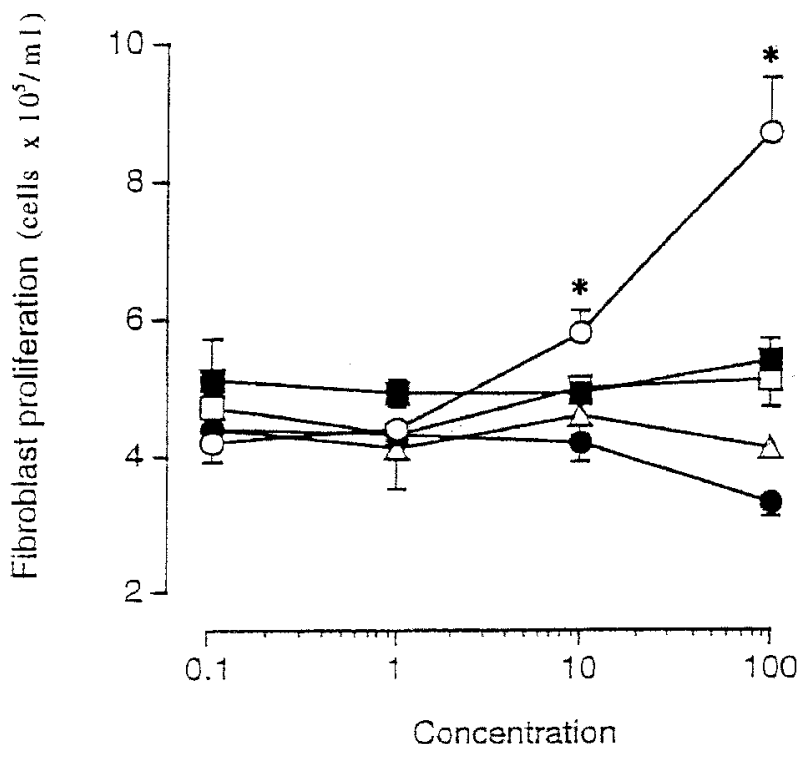

FIG. 1. Lung fibroblast cell proliferation due to PDGF $(0.1-100 \mathrm{ng} / \mathrm{ml}$, open circles) and to heparin $(0.1-100 \mathrm{U} / \mathrm{ml}$, closed circles), heparan sulphate $(0.1-100 \mu \mathrm{g} / \mathrm{ml}$, closed squares) de-N-sulphated heparin $(0.1-100 \mu \mathrm{g} / \mathrm{ml}$, open squares), and poly-L-gultamic acid $(0.1-100 \mu \mathrm{g} / \mathrm{ml}$, open triangles) in the absence of PDGF. The number of cells in the absence of any drug was $4.3 \pm 0.2 \times 10^{5} / \mathrm{ml}$. Each point presents the mean ands.e.mean derived from one of three experiments conducted with four replicates for each mean. $p<0.05$ when compared to control.

Accordingly, we examined the effect of heparin (10 and $100 \mathrm{U} / \mathrm{ml})$, heparan sulphate, de-N-sulphated heparin and poly-L-gultamic acid $(100 \mu \mathrm{g} / \mathrm{ml})$ on

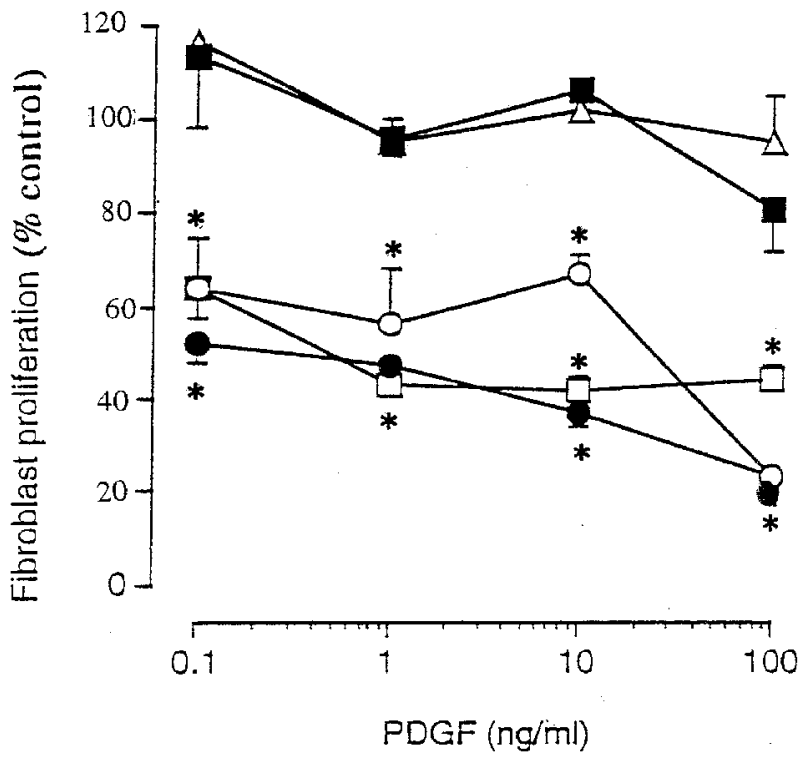

FIG. 2. The effect of heparin $(10 \mathrm{U} / \mathrm{ml}$, open circles; $100 \mathrm{U} / \mathrm{ml}$, closed circles), heparan sulphate $(100 \mu \mathrm{g} / \mathrm{ml}$, closed squares), de-N-sulphated heparin $(100 \mu \mathrm{g} / \mathrm{ml}$, open squares) and poly-L-gultamic acid $(100 \mu \mathrm{g} / \mathrm{ml}$, open triangles) on lung fibroblast cell division induced by PDGF $(0.1-100 \mathrm{ng} / \mathrm{ml})$. Each point represents the mean and s.e.mean derived from one of three experiments conducted with four replicates for each mean. $p<0.05$ compared with the value for PDGF treatment only. 
Table 1. The effects of heparin and heparan sulphate on the incorporation of $\left[\mathrm{H}^{3}\right]$-thymidine by fibroblasts treated with PDGF

\begin{tabular}{lccc}
\hline & Control & PDGF $(1 \mathrm{ng} / \mathrm{ml})$ & PDGF (10 ng/ml) \\
\hline Heparin & & & $142 \pm 15$ \\
$\quad 0$ & 100 & $136 \pm 7$ & $224 \pm 18$ \\
$1 \mathrm{U} / \mathrm{ml}$ & $124 \pm 8$ & $73 \pm 10$ & $268 \pm 18$ \\
$10 \mathrm{U} / \mathrm{ml}$ & $67.4 \pm 4$ & $55 \pm 7$ & $202 \pm 13$ \\
$100 \mathrm{U} / \mathrm{ml}$ & $38 \pm 3$ & & $81 \pm 5$ \\
Heparan sulphate & & $142 \pm 15$ & $224 \pm 18$ \\
$\quad 0$ & 100 & $150 \pm 26$ & $226 \pm 11$ \\
$1 \mu \mathrm{g} / \mathrm{ml}$ & $114 \pm 12$ & $137 \pm 32$ & $242 \pm 18$ \\
$10 \mu \mathrm{g} / \mathrm{ml}$ & $125 \pm 20$ & $147 \pm 35$ & $244 \pm 20$ \\
$100 \mathrm{mg} / \mathrm{ml}$ & $122 \pm 17$ & & \\
\hline
\end{tabular}

Values represent mean \pm s.e.mean of the proliferative response above basal levels derived from experiments with six replicates, each mean represents a significant increase $(p<0.05)$ or significant decrease $(p<0.05)$ in the proliferation of fibroblast when compared with control.

PDGF-induced fibroblast proliferation. In the absence of glycosaminoglycan, PDGF-induced proliferation was unaffected by any vehicle as shown by a stimulation index of near unity (Fig. 2). Heparin and de-N-sulphated heparin significantly inhibited PDGF $(0.1-100 \mu \mathrm{g} / \mathrm{ml})$ induced fibroblast prolife ration (Fig. 2, $p<0.05)$. In contrast heparan sulphate and poly$L$-gultamic acid had no effect on PDGF-induced fibroblast proliferation (Fig. 2). Cell viability assessed using trypan blue exclusion was found to be greater than $95 \%$ in all experiment.

\section{$\left[\mathrm{H}^{3}\right]$-thymidine incorporation assay}

PDGF induced a concentration-related increase in cell prolife ration $(142 \pm 15 \%$ at $1 \mathrm{ng} / \mathrm{ml}, p<0.05 ; 224 \pm 18 \%$ at $10 \mathrm{ng} / \mathrm{ml}, p<0.01)$ as assessed by $\left[\mathrm{H}^{3}\right]$-thymidine

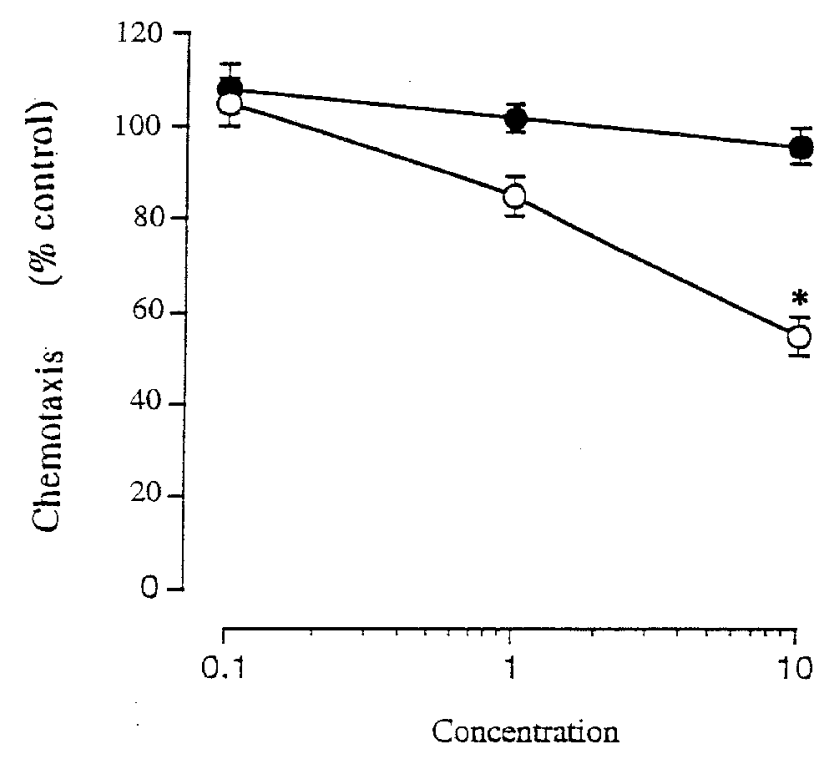

FIG. 3. Inhibitory effects of heparin (U/ml; open circles) and heparan sulphate $(\mu \mathrm{g} / \mathrm{ml}$; closed circles) on PDGF-induced human lung fibroblast chemotaxis. The responses are expressed as SI. Each point is the average of triplicate values from 3 experiments. Vertical lines represents.e. mean. $p<0.05$ when compared with PDGF. incorporation. In agreement with the data obtained when assessing cell proliferation by cell counting, heparin $(10$ and $100 \mathrm{U} / \mathrm{ml})$ significantly inhibited PDGF-induced proliferation (Table $1, p<0.05$ ) In contrast, heparan sulphate $(100 \mu \mathrm{g} / \mathrm{ml})$ had a synergistic effect upon PDGF $(10 \mathrm{ng} / \mathrm{ml})$-induced fibroblast prolife ration (Table 1), but not significantly.

\section{Effect of heparin and heparan sulphate on chemotaxis}

PDGF induced a significant increase in fibroblast chemotaxis (control cell number $=4.2 \pm 1.2$ vs PDGF $=15.0 \pm 4.2, p<0.05)$.

Heparin inhibited fibroblast chemotax is in a concentration-dependent manner (Fig. 3). Che motax is (\%

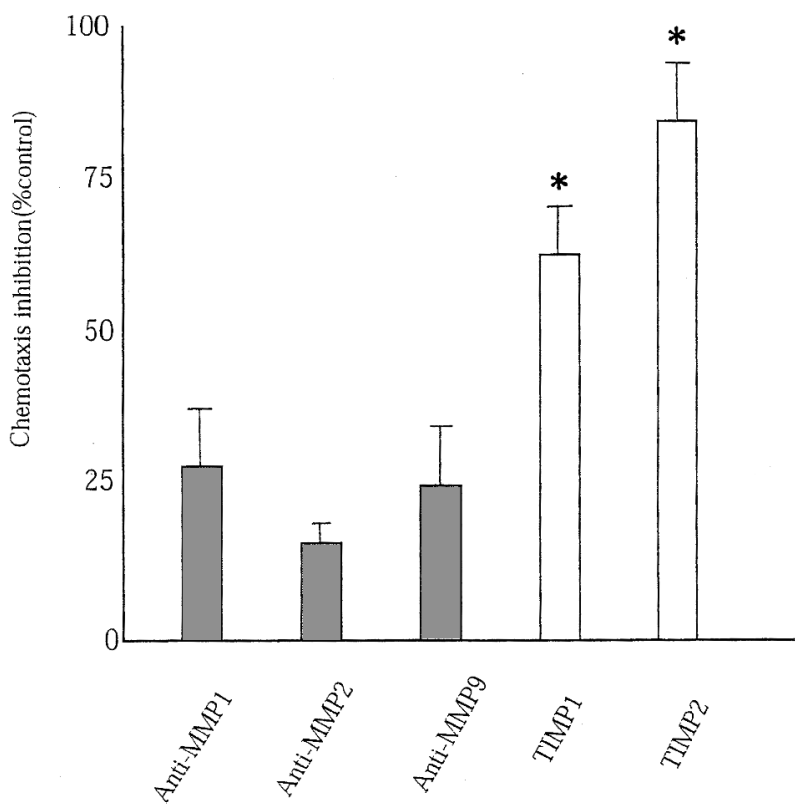

FIG. 4. Effect of anti-MMP1, anti-MMP2, anti-MMP9, TIMP-1 and TIMP-2 on PDGF-induced chemotaxis of fibroblasts. Data are shown as the means \pm s.e.mean. Statistical difference compared to responses in the presence of the same subtype of each lgG at a $p<0.05$ level. 

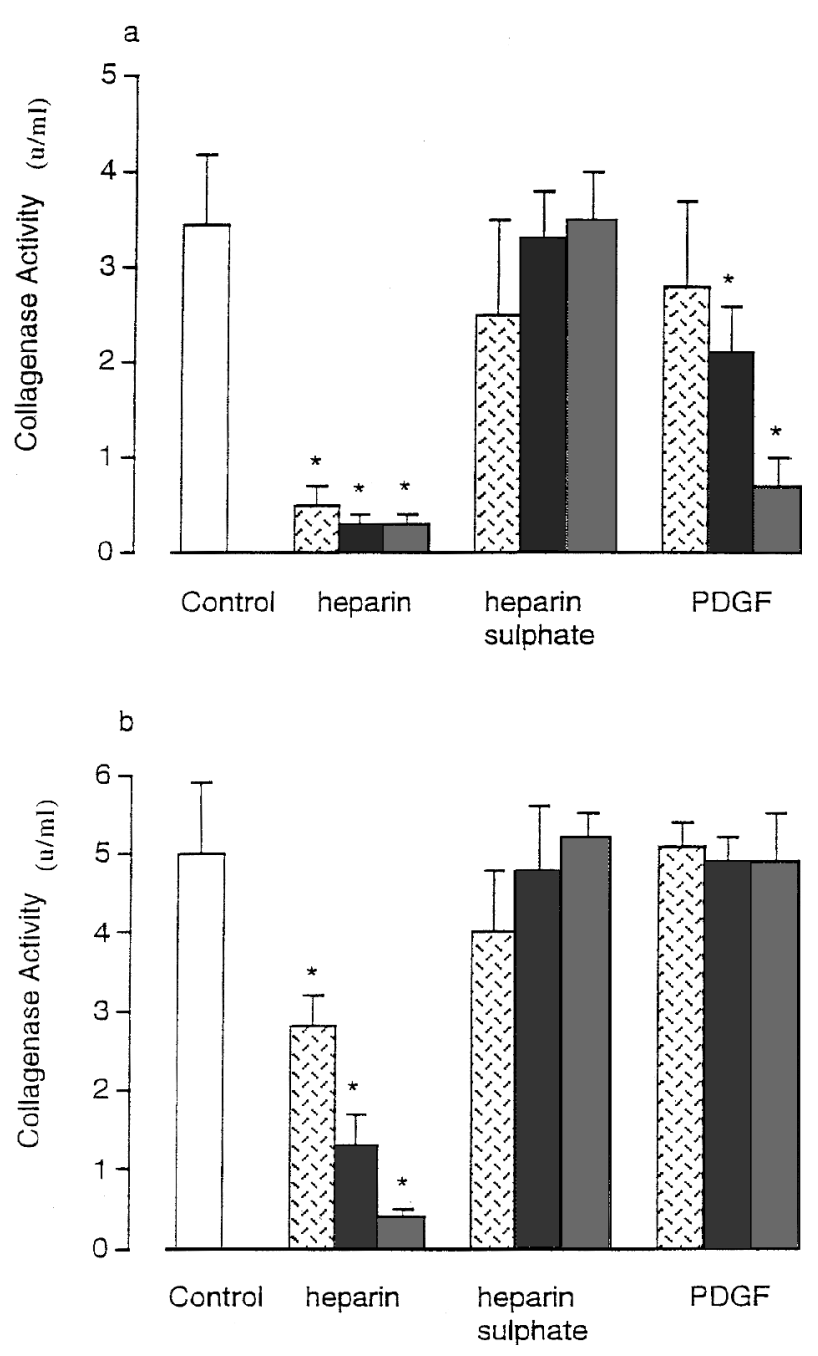

FIG. 5. Bar graph representing the effect of heparin $(1 \mathrm{U} / \mathrm{ml}$, cross-hatched column; $10 \mathrm{U} / \mathrm{ml}$, dark-shaded column; $100 \mathrm{U} / \mathrm{ml}$, light-shaded column), heparan sulphate and PDGF ( $1 \mu \mathrm{g} / \mathrm{ml}$, cross-hatched column; $10 \mu \mathrm{g} / \mathrm{ml}$, dark-shaded column; $100 \mu \mathrm{g} / \mathrm{m}$, light-shaded column): on (a) MMP-1, and (b) MMP-2/MMP-9 activity in lung fibroblasts. One unit of collagenase activity is defined as the amount of enzyme degrading $1 \mu \mathrm{g}$ of collagen per minute. Vertical lines represent s.e.mean from 6 experiments. $p<0.05$ when compared with control.

of control) was significantly lower at $10 \mathrm{U} / \mathrm{ml}$ of heparin than at any other concentration $(p<0.05)$ between $0.1-10 \mathrm{U} / \mathrm{ml}$. In contrast, heparan sulphate $(0.1-10 \mu \mathrm{g} / \mathrm{ml})$ had no significant effect on PDGFinduced fibroblast chemotax is.

Anti-hMMP1, anti-hMMP2 and anti-hMMP9 had no significant effect on fibroblast chemotaxis, while recombinant hTIMP-1 and hTIMP-2 inhibited fibroblast chemotaxis significantly (Fig. 4).

\section{Matrix metalloproteinases assay}

Fibroblasts constitutively express MMP-1 (control levels $=3.45 \pm 0.52 \mathrm{unit} / \mathrm{ml}$ ) and MMP-2/MMP-9 (control levels=5.0 \pm 0.9 unit $/ \mathrm{ml}$ ) collagen activity. PDGF significantly inhibited fibroblast collagenase activity as assessed by a reduction in MMP-1 but not MMP2/MMP-9 collagenase activity (Fig. 5, $p<0.05$ ). Heparin but not heparan sulphate inhibited fibroblast MMP-1 and MMP-2/MMP-9 collage nase activity (Fig. 5, $p<0.05$ ).

\section{RT-PCR}

PCR using specific oligonucleotide primer sets for MMP-1, MMP-2 and MMP-9 revealed a single amplification product of fibroblast cultured with PDGF. Heparin and heparan sulphate had no inhibitory effect on the induction of MMP-1, MMP-2 and MMP-9 gene expression (data not shown).

\section{Discussion}

We demonstrated the ability of PDGF to modulate the induction of MMPs and the activity of MMPs in the present study. Only heparin inhibited fibroblast proliferation, chemotaxis and MMPs activity. Our data suggests that heparin and related glycosaminoglycans differentially regulate PDGF-induced lung fibroblast prolife ration, chemotax is and MMPs activity and may play a key role in extracellular matrix remodeling in inflammatory lung diseases.

Several previous studies suggested that intestitial lung diseases are diffuse inflammatory disorders characterized by an increase in the number of inflammatory cells, fibroblast proliferation, progressive alteration of alveolar-capillary structures and excessive synthesis and deposition of the ex tracellular matrix protein. These phenomena are induced by various growth factors, cytokines and proteases produced by infiltrating neutrophils, platele ts, macrophages, fibroblasts and residential cells. In addition, biopsy specimens from the lungs of patients with pulmonary fibrosis show increased numbers of mast cells ${ }^{1-3}$ which have metachromatic granules acting as growth factors, containing heparin, histamine and proteases. Matrix metalloproteinase also contributes to the role of extracellular matrix turnover and remodeling in pulmonary fibrosis. However, less is known about the interaction of fibroblasts, grow th factor and extracellular matrix molecules in inflammation.

PDGF is one of the most important chemoattractants and mitogens $s^{24,25}$ associated with tissue repair, a process involving collagen synthesis and remodeling by MMPs. PDGF-like mitogen localized in the macrophages and epithelial cells of patient with idiopathic pulmonary fibrosis has been shown to be an important stimulus for fibroblast proliferation and collagen production. ${ }^{26}$ Our present study has demonstrated the ability of PDGF to induce human fibroblast chemotaxis using cell migration assay and to induce proliferation as assessed by cell counting and $\mathrm{H}^{3}$-thymidine incorporation methods. 
Heparin, a major component of the mast cell granule matrix, is well known as a polyanionic anticoagulant. Heparin related glycosaminoglycans are abundant components of the ex tracellular matrix molecules and are present on cell surfaces in many tissues. Heparin and related glycosaminoglycans have been reported to inhibit bovine airway smooth muscle division in a concentration-dependent fashion. ${ }^{16}$ Similarly, heparin-like glycosaminoglycans have been reported to inhibit the grow th of human arterial smooth muscle cells in vitro ${ }^{15}$ by binding and inactivating PDGF and also that heparan sulphate regulated the activity of FGF on fibroblast proliferation and migration. ${ }^{27}$ These studies illustrate that the anti-prolife rative activity of the heparin-like molecule is not limited to airway and vascular smooth muscle but also to human lung fibroblasts.

It is clear that while low concentrations of heparin were ineffective against cell proliferation and DNA synthesis. Heparin at high concentrations inhibited cell proliferation and also DNA synthesis in fibroblasts. This effect is unrelated to a loss in cell viability, as assessed by trypan blue exclusion. Furthermore, the inhibitory effect of heparin was unrelated to its anionic charge since other polyanionics including poly-L-gultamic acid and heparan sulphate had no effect on cell proliferation. Moreover, sulphation does not appear to be necessary for the inhibitory action of heparin on cell proliferation or DNA synthesis since de-N-sulphated heparin was as effective as heparin in this response. It remains unclear whether the effect of heparin and de-N-sulphated heparin on cell proliferation is related to the chemical inactivation of PDGF. Heparin also inhibited fibroblast migration in the present study, whereas exogenously-administered heparin is known to inhibit cell migration. These findings suggest that endogenously related heparins may inhibit inflammatory cell infiltration by producing an anti-inflammatory effect. Indeed, inflammatory cells are major sources of heparanase which disrupts glycosaminoglycan linkages and results in the release of heparin-like fragments from cellular heparan sulphate. ${ }^{28,29}$

Persistent inflammation in the airway may thereby influence structural changes including collagen deposition beneath the basement membrane and airway smooth muscle layer thickening as observed in asthma. ${ }^{30-32}$ Recent studies have indicated that matrix metalloproteinases play a role in the degradation of extracellular matrix protein in tumor cell invasion ${ }^{33,34}$ and neutrophil migration. ${ }^{35}$ Our present results show that human lung fibroblasts in culture retain MMP-1 and MMP-2/MMP-9 activity. MMP1 -interstitial collagenase in fibroblasts-catalyses degradation of collagens, type I, II, III and others. MMP2/MMP-9 has the ability to degrade a wide range of extracellular matrix proteins, including basement membrane collagen type IV, fibronectin and gelatin.
Our results demonstrate that PDGF inhibits MMP-1 but not MMP-2/MMP-9 activity in a concentrationdependent fashion and that PDGF differentially regulates MMPs activity, fibroblast proliferation and chemotaxis. We recommend that further studies investigate the effects of PDGF in the regulation of MMPs.

Little is known about the interaction between heparin and MMPs. Our results are significant in the understanding of fibroblast migration to the basement membrane and extracellular matrix and also of the inhibitory effects of heparin on fibroblast migration. We observed that blocking the endogenous MMPs with anti-hMMP1, anti-hMMP2 and anti-hMMP9which have no effect on the catalytic site of each MMPs-had no effect on fibroblast chemotaxis. In contrast, recombinant h TIMP-1 and hTIMP-2 inhibited fibroblast chemotaxis significantly, which is consistent with the notion that fibroblast migration was thought to be dependent on degradation of collagen. The ability of heparin to inhibit fibroblast chemotax is may account for the inhibitory effects of heparin on MMPs activity. This hypothesis is further supported by our result that heparin had no inhibitory effect on induction of MMP-1 and MMP-2/MMP-9 mRNA. Further experiments are required to understand the mechanism by which heparin inhibits MMPs activity.

In conclusion, our results provide clear evidence that heparin inhibits PDGF-induced human lung fibroblast proliferation, chemotax is and MMPs activity. Thus, endogenously-released heparin-like molecules may play an important role in extracellular matrix turnover and remodelling in inflammatory lung diseases.

ACKNOWLEDGMENTS: This w ork was supported in part by a Grant-in-Aid for Scientific Research C (07670653) from the Ministry of Education, Science and Culture, Japan.

\section{References}

1. Kawanami O, Ferrans VJ, Fulmer JD, Crystal RG. Ultrastructure of pulmonary mast cells in patients with fibrotic lung disorders Lab Invest 1979:40:717-34

2. Fortoul TI, Barrios R. Mast cells and idiopathtic lung fibrosis. Arch Invest Med 1990:21:5-10.

3. Heard B, Dewar A, Corrin B. Apposition of fibroblasts to mast cells and lymphocytes in normal human lung and in cryptogenic fibrosing alveolitis. Ultrastructure and cell perimeter measurements. J Pathol 1992: 166:303-10.

4. Selman M, Montano M, Ramps C, Chapel R. Concentration, biosynthesis and degradation of collagen in idiopatic pulmonary fibrosis. Thorax 1986:41:355-9.

5. Raugh GL. Ex tracellular matrix in normal and fibrotic human lungs. $A m$ Rev Res Dis 1985:131:281-9.

6. Ross R, Raines RE, Bowen-Pope DF. The biology of platelet derived grow th factor. Cell 1986:46:155-69.

7. Martinet Y, Rom WN, Grotendorst GR, Martin GR, Crystal RG. Exaggerated spontaneous release of platelet-derived grow th factor by alveolar macrophages from patients with idiopathic pulmonary fibrosis. $N$ EnglJ Med 1987:317:202-9.

8. Butler DM, Leizer T, Hamilton JA. Stimulation of human synovial fibroblast and synthesis by platelet-derived grow th factor and fibrobast grow th factor. J Im munol 1989:142:3098-103.

9. Colvin RB, Johnson RA, Mihm MC, Dvorak HF. Role of the clotting system in cell-mediated hypersensitivity. Fibrin deposition in delayed skin reaction in man. J Exp Med 1973:138:686-98. 
10. Schwartz LB, Bradford TR. Regulation of tryptase from human lung mast cells by heparin stabilization of the active tetraminer. Biol Chem 1986:261:7372-9.

11. Sayama S, Iozzo RV, Lazarus GS, Schechter NM. Human skin chymotrypsintike proteinase chymase. Subcellular location to mast cell granules and interaction with heparin and other glycosaminoglycans. Bio Chem 1987:262:6808-15.

12. Lider O, MekoriYA, Miller T, Bar-Tana R, Vlodavsky I, Baharav E, Cohen I $\mathrm{R}$, Naparstek Y. Inhibition of $\mathrm{T}$ lymphocyte heparanase by heparin prevents T cell migration and Tcell-mediated immunity. Eur J Imm unol 1990:20:493-9.

13. Seeds EAM, Hanss J, Page CP. The effect of heparin and related proteogrycans on allergen and PAF-induced eosinophil infiltration. $J$ Lipid Mediators 1993:7:269-78.

14. SasakiM, Herd CM, Page CP. Effect of heparin and a low-molecular weight heparinoid on PAF-induced airway responses in neonatally immunized rabbits. Br J Pharmacol 1993:11 0:107-12.

15. Fager G, Hansson GK. Humanarterial smooth muscle cells in culture. Effects of platelet-derived grow th factor and heparin on grow th in vitro. Exp Cell Res 1988:176:319-35.

16. Kilfeather SA, Tagose S, Perez AC, Okona-Mensa K, Martin R, Page CP. Inhibition of serum-induced proliferation of bovin tracheal smooth muscle cells in culture by heparin and related grycosaminogrycans. $\mathrm{Br} \mathrm{J}$ Pharmacol 1995:114:1442-6.

17. Karnovsky MJ, Edelman ER. Heparin/heparansulphate regulation of vascular smooth muscle behaviour. In: Blac J, Page CP, eds. Airways and Vascular Remodelling in Asthma and Cardiovascular disease implica tion for Therapeutec Intervention. London: Academic Press, 1994.

18. Bowler SD, Smith SM, Lavercombe PS. Heparin inhibits the immediate response to antigen in the skin and lungs of allergic subjects. Am Rev Respir Dis 1993:147:160-3.

19. Chin JR, Murphy G, Werb Z. Stromelsin, a connective tissue-degrading metalloendopeptidase secreted by stimulated rabbit synovial fibroblasts in parallel with collagenase. J Biol Chem 1985:260:12367-76.

20. Himelstein B, Canete-Soler R, Bernhard EJ, Muschel R. Induction of fibroblast $92 \mathrm{kDa}$ gelatinase/type IV collagenase expression by direct contact with metastatic tumor cells. J Cell Sci 1994:107:477-86.

21. Gadek JE, Kelman JA, Fills G, Weinberger SE, Horwitz AL, Reynolds HY, Bulmer J, Crystal RG. Collagenase in the lower respiratory tract of patients with idiopathic pulmonary fibrosis. $N$ Engl $J$ Med 1978:301:737-42.

22. Erkell LJ, Schirrmacher V. Quantitative in vitro assay for tumor cell invasion through extracellular matrix or into protein gels. Cancer Res 1988:48:6933-7.

23. Harris ED, Vater CA. Method in Enzymology 1982:82:423-52.
24. Seppa H, Grotendorst G, Seppa S, Schiffmann E, Martin GR. Plateletderived growth factor is chemotactic for fibroblasts. J Cell Biol 1982:92:584-8

25. Antoniades HN, Bravo MA, Avila RE, Galanopoulos T, Neville-Golden J, Maxwell M, Selman M. Platelet-derived growth factor in idiopathic pulmonary fibrosis. J Clin Invest 1990:86:1055-64.

26. Martinet Y, Rom WN, Grotendorst GR, Martin GR, Crystal RG. Exaggerated spontaneous release of platelet-drived grow th factor by alveolar macrophages from patients with idiopathic pulmonary fibrosis. $N$ EnglJ Med 1987:317:202-9.

27. Butler DM, Leizer T, Hamilton JA. Stimulation of human synovial fibroblast and synthesis by platelet-derived grow th factor and fibroblast grow th factor. J Im munol 1989:142:3098-103.

28. Unemori EN, Ehsani N, Wang M, Lee S, Mcguire J, Amento EP. Interleukin1 and transforming growth factor- $\beta$ :synergistic stimulation of metalloproteinases, PGE2, and proliferation in human fibroblasts. Exp Cell Res 1994: 210:166-71.

29. Yahalom J, Eldor A, Fuks Z, Vlodavsky I. Degradation of sulfated proteoglicans in the subendothelial extracellular matrix by human platelet heparitinase. J Clin Invest 1984:74:1842-9.

30. Lundgen R, Soderberg M, Horstedt P, Stenling R. Morphological studies of bronchial mucosal biopsies from asthmatics before and after ten yeares of treatment with inhalated steroid. Eur Respir J 1988:1:883-9.

31. Ebina M, Yaegasi H, Chiba R, Takahasi T, Motomiya M, Tanemura M. Hyperreactive site in the airway tree of asthmatic patients revealsed by thicking of bronchial muscles: A morphometric study. Am Rev Respir Dis 1990: 14:1327-32.

32. Roche WR, Beasley CE, Williams JH, Holgate ST. Subepithlial fibrosis in the bronch of asthmatics. Lancet 1989:i:520-8.

33. Kataoka H, DeCastro R, Zucker S, Biswas C. Tumor cell-derived collagenase-stimulatory factor increase expression of interstitial collagenase stomelysin, and $72-\mathrm{kDa}$ gelatinase. Cancer Res 1993:53:3154-8.

34. Ito A, Nakajima S, Sasaguri Y, Nagase H, Mori Y. Co-culture of human breast adenocarcinoma MCF-7 cells and human dermal fibroblasts enhances the production of matrix metalloproteinases 1,2 and 3 in fibroblasts. Br J Cancer Res 1995:71:1039-45.

35. Delclaux C, Delacourt C, d'Ortho M, Boyer V, Lafuman C, Harf A. Role of gelainase $\mathrm{B}$ and elastase in human polymorphonuclear neutrophil migration across basement membrane. Am J Respir Cell Mol Biol 1996: 14:288-95.

\section{Accepted 2 May 2000}




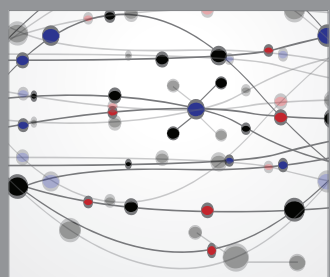

The Scientific World Journal
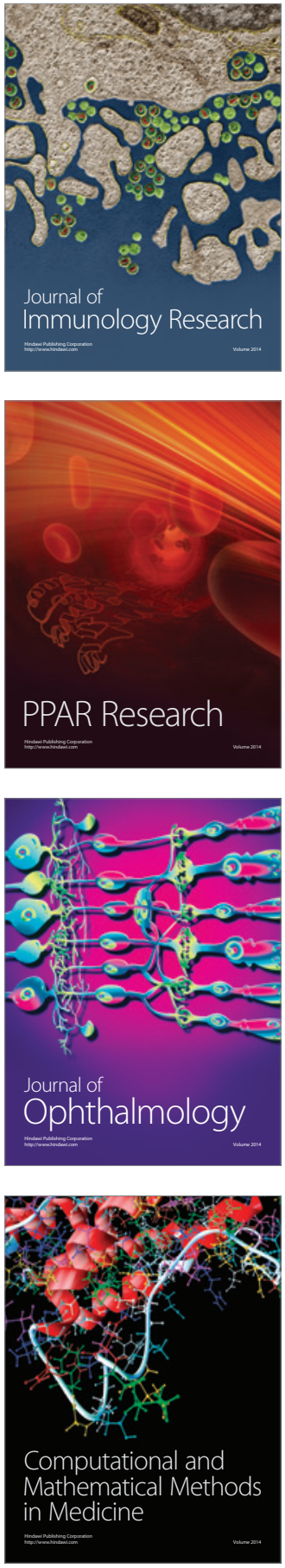

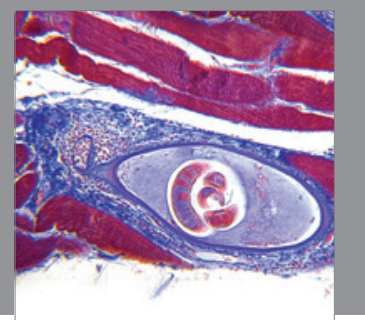

Gastroenterology

Research and Practice
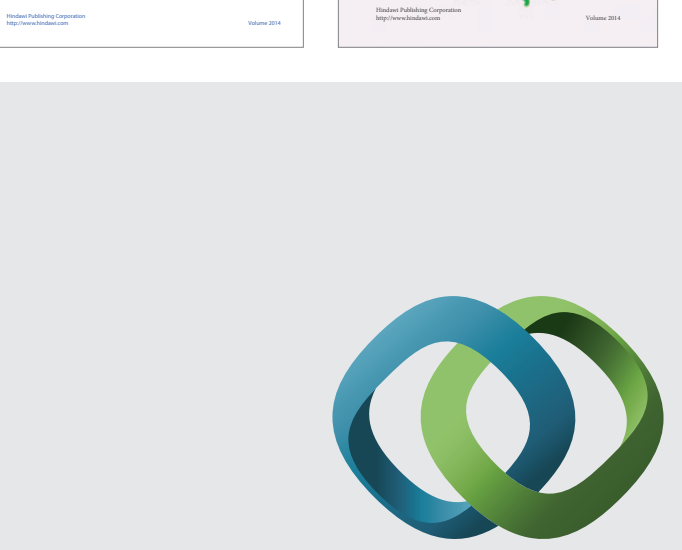

\section{Hindawi}

Submit your manuscripts at

http://www.hindawi.com
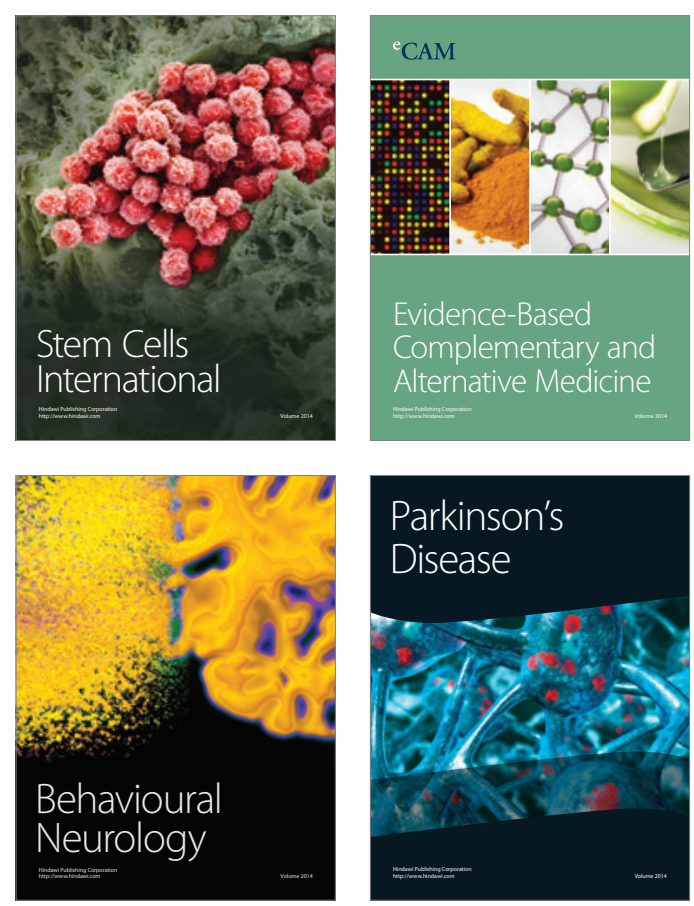

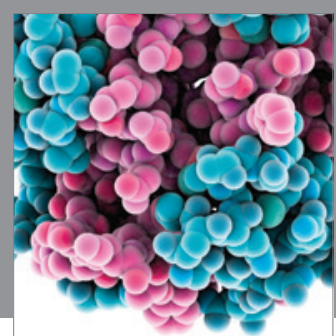

Journal of
Diabetes Research

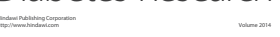

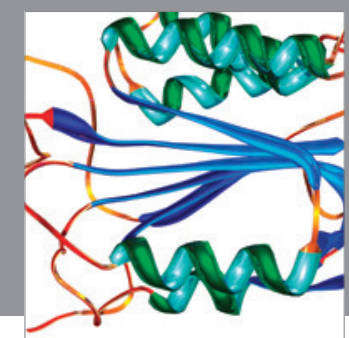

Disease Markers
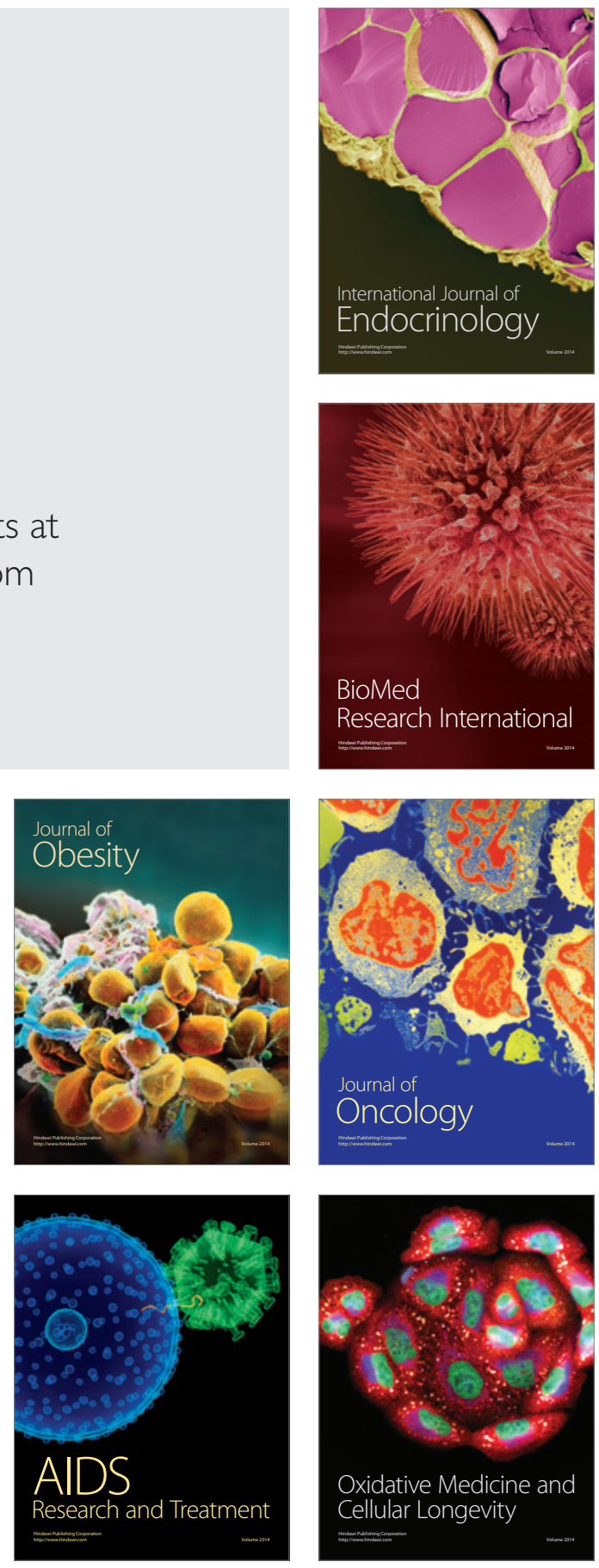